\title{
White Fang Ally: The Arctic As Eden of Death in 30 Days of Night
}

\author{
Kwasu David Tembo \\ Ashesi University, Ghana - tembo.kwasu@gmail.com
}

\begin{abstract}
A recurrent congenital weakness of $20^{\text {th }}$ and $21^{\text {st }}$ century television, literature, and cinema vampires is their porphyric susceptibility to ultraviolet radiation. Central to vampires' continued undead life is the problem of sunlight. In this way, sunless environs like the Arctic and Antarctic represent what I describe as purely Gothic environments in whose desolation, cold, and darkness, undead life is able to proliferate, unmarred and unimpeded by the typical diurnal/nocturnal cycles of luminosity that trouble the undead lives of vampires. In order to theorize the value of the Arctic as an embodiment of Gothic-horror,

this essay uses Steve Niles and Ben Templesmith's 30 Days of Night (2002) as a case study of the pathetic resonances between the Arctic and the figure of the vampire. Following on from this, the analysis turns to Michel Foucault's concept of the heterotopia in order to theorize the manner in which the Arctic, whose nocturnal/diurnal rhythms stand in radical opposition to the majority of seasonal cycles elsewhere on earth, represents an ontoexistential paradise of death for the undead: a chronotope that embodies the essential attributes of the onto-existential condition of the undead.
\end{abstract}

Keywords: 30 Days of Night, vampire, Arctic; gothic, horror, heterotopia.

\section{Aliado de Presas Brancas: O Ártico como Paraíso da Morte em 30 Days of Night}

\section{Resumo}

Uma recorrente fraqueza congénita dos vampiros que povoam a televisão, literatura e cinema dos séculos XX e XXI é a sua suscetibilidade porfírica à radiação ultravioleta. O problema da luz solar é fundamental para a continuidade existencial morta-viva dos vampiros. Desta forma, ambientes sem sol, como o Ártico e a Antártica, representam ambientes puramente góticos, em cuja desolação, frio e escuridão a vida não-morta é capaz de proliferar sem ser perturbada pelos ciclos diurnos / noturnos de luminosidade que tradicionalmente restringem os vampiros. Com o objetivo de teorizar o valor do locus Ártico enquanto personificação do terror gótico, este ensaio recorre a 30 Days of Night (2002) de Steve Niles e Ben Templesmith como estudo de caso das ressonâncias entre o Ártico e a figura do vampiro. Num segundo momento, a análise foca o conceito

(C) The Author(s) 2021. Open access article published online by Interações: Sociedade e as Novas Modernidades, ISSN: 2184-3929, at https://interacoes-ismt.com, under the terms of the Creative Commons Attribution-NonCommercial 4.0 International Licence (https://creativecommons.org/ 11 licenses/by-nc/4.0). 
de heterotopia de Michel Foucault para teorizar a maneira como o Ártico, cujos ritmos noturnos / diurnos se opõem radicalmente à maioria dos ciclos sazonais em outras partes da Terra, representa um paraíso ontoexistencial de morte para os não-mortos: um cronótopo que incorpora os atributos essenciais da condição ontoexistencial dos mortos-vivos.

Palavras-chave: 30 Days of Night, vampiro, Árctico, gótico, horror, heterotopia.

Morn came and went-and came, and brought no day, And men forgot their passions in the dread

Of this their desolation; and all hearts Were chill'd into a selfish prayer for light:

Lord Byron, "Darkness"

\section{INTRODUCTION}

Set in Barrow Alaska, the original 30 Days of Night (hereon 30 Days) illustrated by Ben Templesmith, written by Steve Niles, is a 3 part miniseries published by IDW in 2002. While the original miniseries was published in a 22 page comic book, the unexpected albeit vehement success of the original miniseries resulted in the expansion of the diegesis through several spin-offs, films and novels. These include Steve Niles and Jeff Mariotte's co-authored novels 30 Days of Night: Rumours of the Undead (2006), 30 Days of Night: Immortal Remains (2007), and 30 Days of Night: Eternal Damnation (2008); Ben Ketai's 2007 film adaptation 30 Days of Night, and David Slade's 2010 direct to DVD followup 30 Days of Night: Dark Days; as well as numerous comic arcs that expanded the world of the original miniseries including but not limited to 30 Days of Night: Dark Days (2003) by Niles and Templesmith. In terms of this body of work, the remit of this essay is strictly Niles and Templesmith's original 3 part miniseries.

The diegetic world established by Niles and Templesmith is relatively straightforward. The narrative of the miniseries rests on a central climatological phenomenon experienced in Barrow. Being as far north as it is, the town endures 30 days of uninterrupted darkness during winter. This instantiates a rare, albeit naturally caused circumstance, in which vampires (also known in the series as nosferatu) can take advantage of the dark and feed on the inhabitants of Barrow at will, without having to 
sleep to avoid fatal exposure to ultraviolet radiation. Implemented by the punk-Goth Marlow, second-in-command of the handful of remaining vampires that survived human persecution, the rag-tag coven descends on Barrow as if attending an exclusive banquet. The comic opens with a mystery: all the cell phones of the town's inhabitants have been gathered into a pile and burned on the outskirts of the town. The vampire's familiar, an unnamed scruffy and severely psycho-emotionally traumatized man who seeks to be turned, has infiltrated the town an undisclosed amount of time in the prehistory of the story (Niles, 2002, p.9). Like a blackly humorous pastiche of a sous chef, he kills all the sleigh dogs, and destroys the town's generator station - all of which are part of a coordinated effort to sever the frigid connection between the already naturally isolated Barrow and the outside world (Niles, 2002, p.17). It is, from the vampires' perspective, a tactic as efficient and necessary for a banquet as calling in a caterer. In this sense, to a vampire, Barrow is part theme park, part buffet.

On hearing of Marlow's plan, the true leader of all remaining vampires in the 30 Days diegesis, Vicente, races to Barrow in an attempt to intercept his underling, prevent the feeding, and with it, the risk of re-exposing vampire existence to humankind. He arrives too late to prevent both the initiation of slaughter or its completion because the extreme cold, while protecting the vampires from sunlight, also has the physiological effect of interrupting the keenness of their already supernaturally enhanced senses. As a direct result, some of the townspeople, including Sheriff Eben Olemaun, the text's protagonist, are able to evade detection. With short supplies, and having to endure the pressure of having to constantly obfuscate the presence of the infirm, the elderly, children, women, and men, Olemaun realizes that their chances of survival for the entire 30 day period of darkness are slim to nil. As a last resort, he elects to inject himself with a dose of vampire blood. During his turning, Olemaun challenges Vicente to a fight to the death, which he wins. Having saved the surviving townsfolk, which include his wife Stella, Olemaun watches the sun rise one final time on its return with his wife and subsequently turns to ash.

There seems to be a residual importance of materiality and realism in contemporary critical theory and philosophy pertinent to vampire studies. This can be noted in such works as Graham Harman's Weird Realism: Lovecraft \& Philosophy (2012); the enduring relevance of Lorna Piatti-Farnall's The Vamire in Contemporary Popular Literature (2014), particularly the text's fifth chapter "Vampire Spaces"; and James Tobias' "The Vampire and the Cyborg Embrace: Affect Beyond Fantasy in Virtual Materialism" in Vampires: Myths \& Metaphors of Enduring Evil (2006) edited by Peter 
A. Day. It is not surprising that in said works, theorization of the settings of vampiric fiction as a central conceit often takes the fore. I assert that this is due to the fact that setting in the genre acts as remit, predicate or field within which the supernatural endowments and demerits of the undead are engendered or stymied.

From Bram Stoker's Dracula (1897), F. W. Murnau's Nosferatu (1922), Richard Matheson's I Am Legend (1954), Joss Whedon's Buffyverse (1997-2004), Stephen Norrington's s Blade (1998), Tomas Alfredson's Let The Right One In (2008), to The Spierig Brothers' Daybreakers (2009), a recurrent congenital weakness of the hominus nocturna of $20^{\text {th }}$ and $21^{\text {st }}$ century television, literature, and cinema is their porphyric susceptibility to ultraviolet radiation. From the onto-existential perspective of the vampire, central to its continued undead life is the problem of sunlight, the sun accruing symbolic value for the undead as a type of inescapable horror of nature. The reverse is equally as true, whereby sunless environs like the Arctic and Antarctic represent what I describe as purely Gothic environments in whose desolation, cold, and darkness, undead life is able to proliferate, unmarred and unimpeded by the typical diurnal/nocturnal cycles of luminosity which act as an onto-existential limit on the undead lives of vampires.

In order to theorize the value of the Arctic as a literal spatiotemporal embodiment of Gothic horror, this essay seeks to use Niles and Templesmith's 30 Days as a dialogic case study of the pathetic resonances between the Arctic and the figure of the vampire. Following on from this, I will refer to Michel Foucault's concept of the heterotopia to theorize the manner in which the Arctic, whose nocturnal/diurnal rhythms stand in radical opposition to the majority of seasonal cycles elsewhere on earth, represents what I think of as an onto-existential 'paradise of death' for the undead: a chronotope that embodies the essential attributes of the onto-existential condition of the undead. In other words, the Arctic, specifically the town of Barrow, Alaska, as a heterotopia of death.

It is this paper's contention that because vampire narratives are such a ubiquitous mainstay of popular culture, theorizations of vampires and their respective practices, let alone specifically their environs, typically make recourse to assumptions and lazy stereotypes. Afterall, why trouble yourself with rigorous explications when so much of the subject matter and genre is already assumed? Nevertheless, when discussing any text that declares itself as one that employs the tropes and conventions, conceptual, aesthetic, or narratological, that refer to well-known figures of myth, legend, and folklore, it is important to establish what 'rules' it is adhering to. In Niles and Temple- 
Figure 1

Barrow, Alaska - An Eden of Death
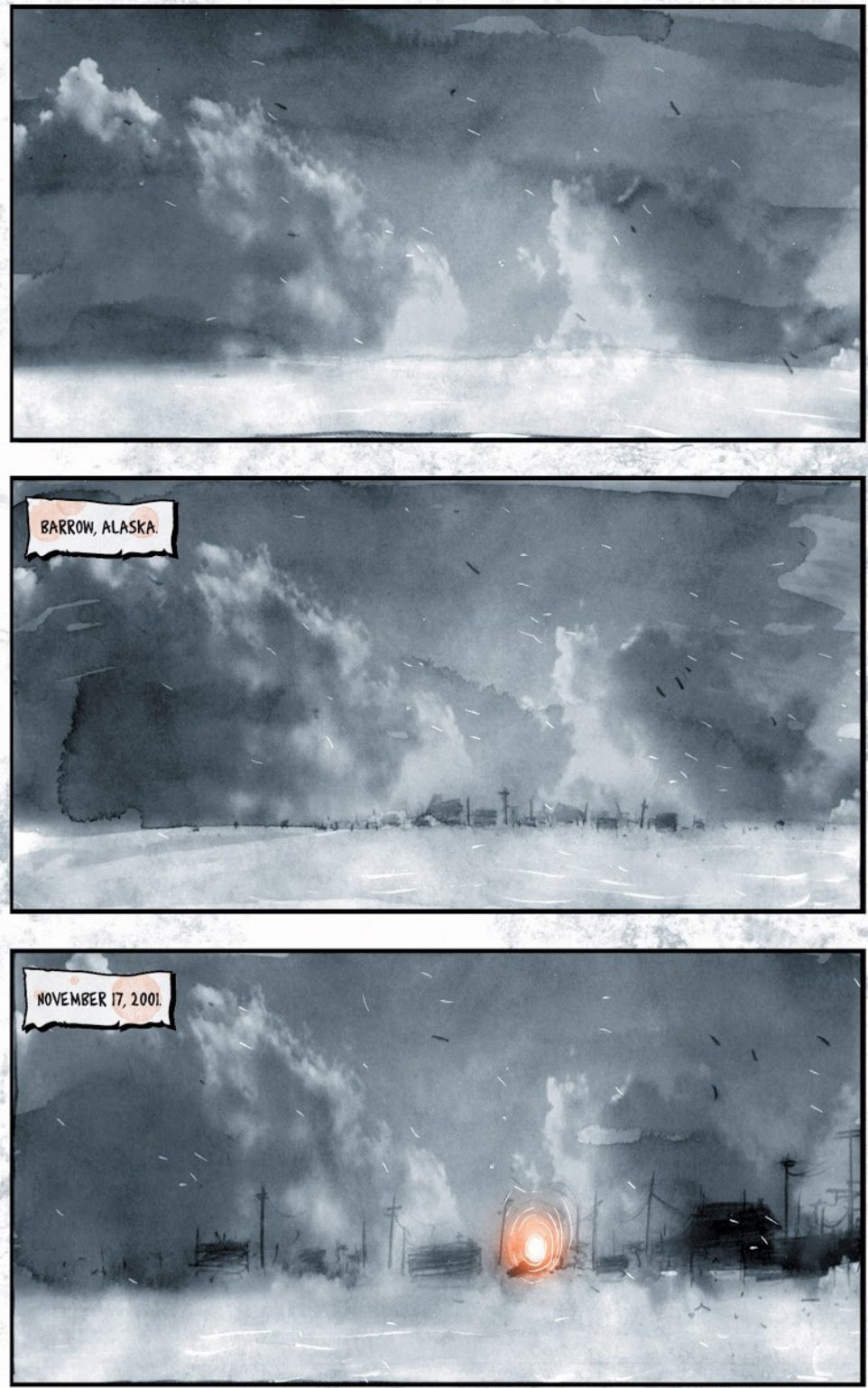
smith's exploration of the history of the nosferatu in the broader 30 Days, it is clear that the creators are employing what could be considered a 'common' vampire ruleset or rubric. The creators' nosferatu were once led by a 'Council of Elders' chaired by Vicente. Following the decision to expose their existence to the human race, most of the nosferatu were hunted and killed, leaving only a handful alive after a millennium of persecution and extermination. Here, the importance of secrecy, surreptitiousness, and stealth are both exacerbated and troubled by the paradoxical open-closedness of Barrow. Where Niles and Templesmith overlap with a vampire luminary and pioneer like Stoker, for example, is on this point of space and personification. Stoker's Dracula offers no notion of a 'vampire society' nor of its genocidal persecution, or any references to the vampires' social structure implied in Niles and Templesmith's 'Council of Elders'. Instead, Stoker places great emphasis on the 'absence' or hidden nature of the human characters' antagonist through numerous techniques of pseudo-presence. These take the form of veiled references, the inexplicable malaise of its victims that only becomes clear when the "mad scientist" Van Helsing enters the narrative in earnest. Where Stoker, Niles, and Templesmith find parity is through setting, what I call high-Gothic Baroque in the former, and Desolation Minimalism in the latter. The remoteness of the places that Dracula, this otherworldly creature, stalks or inhabits (Transylvania) is recaptured in Barrows's sense of radical isolation, emptiness, secrecy, and danger.

Physically, Niles and Templesmith's nosferatu could comfortably and accurately be termed 'common' vampires; in that, their embodiment of vampirism is depicted as viral, spread by scratches, exposure to infected blood, and, of course, bites. After turning, the victim, now undead, gains enhanced physical abilities, such as strength, speed, and superhuman sense of smell, sight, and hearing - all of which are rendered, ironically, useless in the vast wastes of the Arctic tundra. However, in 30 Days, the nosferatu would not necessarily need these endowments to find, kill, and feed on the survivors of their initial onslaught of Barrow and massacre of its residents over a 30 day period. Aside from Templesmith's vivid depiction of physical mutation caused by the virus, which results in the victim growing a mouthful of numerous razor-sharp fangs as well as developing completely black eyes, the nosferatu suffer the same defining congenital weakness as their Gothic forebears: a fatal aversion to sunlight. Unlike their forerunners, however, they are immune to mystical anti-vampiric countermeasures such as garlic, fire, crucifixes, wooden stakes, and/or silver. Being that even the smallest and most diminutive of their number are extremely physically robust, 
the only certain way to dispatch a nosferatu is either by decapitation or exposure to direct sunlight. While the latter renders them to ash, an interesting feature of Niles and Templesmeith's 'rule-set' is that exposing said ash to blood can reanimate the nosferatu in corpore.

Niles introduces the miniseries by stating "the comic in your hands has much of the raw, even brutal, energy of a horror movie from the good old days. Short, sharp, and unforgiving", like a winter, sunless, dark, and cold, a vampire's paradise (Niles, 2002). Niles and Templesmith's aesthetic and narrative approach to the Arctic could be described as an inversion of the following description of that same climate given by Mary Shelley: "the sun is forever visible, its broad disk just skirting the horizon, and diffusing a perpetual splendour," there would be no extensive ice, "and, sailing over a calm sea, we may be wafted to a land surpassing in wonders and in beauty every region hitherto discovered on the habitable globe" (Shelley, 1823, pp. 2-3). The creators achieve this inversion through interpellation, reference, and (re)imagination. In 30 Days, Niles and Templesmith use

conventions of the [vampire] story, the gothic, and horror to produce a dark aesthetics of the Arctic that examines] the physical and psychological responses of humans to a remote and unforgiving environment; probe the boundaries of what counts as material or immaterial; and investigate themes such as place memory, darkness, possession, control, concealment, violence, the unspeakable, and the porous boundaries between the rational and the irrational. (Merola, 2014, pp. 25-6)

In so doing, they create both aesthetic and narrative terror, which Tabish Khair notes, always-already engenders "a possibility (but not the only one) at the border of selfhood and Otherness, Otherness and selfhood" (Khair, 2009, p. 173). In contradistinction to equatorial milieus and/or arid topographies, the tundra's moribund characteristics - cold, dark, and damp - make the bio-geological ecosystems and inter-species networks forming Arctic/Antarctic environments particularly amenable to Gothic and/or Horror aesthetics and narrative explorations and experiments.

Gothic narratives, contemporary or historical, typically avail themselves of certain leitmotifs, symbols, constructs and concepts that refer to the corpus of literature that formed the genre. These include paranoia, isolation, terror, wonder, the Romantic sublime, and a melodramatic onto-existential and psycho-emotional response to 
phenomena that produce such affects. Clive Bloom has suggested that the development of the Occidental Gothic tradition was precipitated by a collective imaginative void left, ironically, as a residue of topographical, geological, scientific, ethnographic, and anthropological discoveries made in and around the period of early post-industrialism. The aforementioned enterprises had the collective effect of evacuating what Carl Jung would term the 'collective unconscious' of its dark nadirs and dim recesses in which lurked wyverns, the fey, lycanthropes, upirs, witches, and golems. In short, the industrialized imagination was voided of the Other in its most radical alterity, its unnerving uncanniness. Coupled with the authority of the scientific method, the exploration of the fringes of the known world and its most remote territories necessarily reduced its mysteries, leaving psycho-imaginative room, so to speak, for the Gothic to emerge (Bloom, 2010, p. 2).

One of the key elements of the Gothic tradition is setting. As De Vore notes,

the setting is greatly influential in Gothic novels [in that] it not only evokes the atmosphere of horror and dread, but also portrays the deterioration of its world. The decaying, ruined scenery implies that at one time there was a thriving world. At one time the abbey, castle, or landscape was something treasured and appreciated. Now, all that lasts is the decaying shell of a once thriving dwelling. (De Vore et al., n.d.).

The Arctic's climatological predisposition to hermeneutics that characterize the space itself as saturnine allows for polyvalent applications of concepts, some paradoxical or dialectically opposed. Examples include decay/preservation, dead/undead, morbid/pristine. In terms of the aesthetic manifestation of this idea in the comic, Niles describes Templesmith's art by stating that

the images throw the bleak world of Barrow into soft focus in order to concentrate our attention on the eyes of the victims, on their blood, or on the delicate symmetry of a set of fangs. It's not pretty. But when was a great horror story ever pretty? [the work represents] a new vein [...] evoking a cold, joyless world in which appetite can never be sated and love gives no comfort. (Barker, 2002)

In its paradoxical convergence of themes of decay and preservation elicited by the image of the endlessness and purity of the tundra, coupled with the preserva- 
tive attributes and connotations of ice, the Arctic can be said to exacerbate the typical tropes of Gothic settings to absurd self-contradiction. In the Gothic/Horror expanse paradoxically opened up and closed off by the Arctic, numerous monsters and revenants have been reterritorialized from quintessential Gothic settings such as the above-mentioned decrepit castles, austere moors, over-canopied forests, and decaying abbeys, and reinserted into the Arctic. As a result, 30 Days can be situated alongside other notable examples of the genre of Arctic/Antarctic horror: from the Arctic milieu Shelley employs as a mise en abime to frame or bookend her seminal text Frankenstein (1818), to the following examples of contemporary film and television texts which include, but are not limited to: Tommy Wirkola's Dead Snow (2009), a zombie film centred on the snowy peninsulas of Norway and revenant Nazis; Gregory Jacobs and Guillermo Del Torro's respective explorations of the cold, ghosts, and isolation in both Wind Chill (2007) and Crimson Peak (2015); Adam Green's Frozen (2010), and similarly Joe Carnhan's The Grey (2011), each of which eschew the necessity of supernatural actors or elements, leaving the environment and the forces of wind and cold to produce a sense of thrill and horror; Dominic Sena's Whiteout (2009) which, like Niles and Templesmith's text, engenders horror through the phenomenon of the Arctic/Antarctic's periods of protracted darkness; Lawrence Kasdan's Dreamcatcher (2003), David Kajganich's 2018 The Terror, a fictionalized account of Captain Sir John Franklin's ill-fated 1845-1848 Arctic expedition; and lastly, perhaps the most famous example of the sub-genre, namely John Carpenter's The Thing (1982), which elides the remote darkness of arctic conditions with secrecy, conspiracy, and aliens.

\section{THE ARCTIC IS A MAW, THE SNOW ITS FANGS: (UN)NATURAL ENVIRONMENTAL DANGERS OF THE TUNDRA}

With the sun not rising from November $18^{\text {th }}$ to December $18^{\text {th }}$, Niles describes Barrow as "a town used to two things: temperatures averaging below zero and darkness" (Niles \& Templesmith, 2002). There are numerous scholarly works and intersectional lines of inquiry that consider the relationship between genre fiction and misanthropic climates. These include analyses that pursue considerations of non-realist and genre fiction and its relationship to ecophobia (Philips, 2003; Trexler, 2012, Trexler \& Johns-Putra, 2011); texts that explore the concept and use of dark ecologies 
(Morton, 2010; Thacker, 2011); works that investigate the ecogothic as an aesthetic and narrative method (Hillard, 2013); as well as texts that examine the relationship between ecocriticism and fear (Mackenzie, 2013; Taylor, 2012).The Arctic, in Niles and Templesmith's hands, engenders a sublime (in the Kantian, Burkean, and Shopenhauerian mode) sense of both beauty and horror at once (Merola, 2014, pp. 23-25). Like Richard Matheson's I Am Legend (1954/1995), which Koenig-Woodyard notes, "composes a narrative of post-apocalyptic solitude nested in an urban adaptation of the castaway narrative, Neville - a "weird Robinson Crusoe, imprisoned on an island of night surrounded by oceans of death"', Barker and Templesmith invert the typical association of the vampire with the decrepit castle, the ruined abbey, and reterritorialize the horror of this Gothic figure from the interiority of these traditional settings into the vast empty danger of the Arctic, as expansive and terrible as desert or sea (Matheson, 1954, p. 72; Koenig-Woodyard, 2018, p. 81).

In the context of 30 Days, this paradoxical merger of forces and responses can be further illuminated if phrased as the following question: What does the Arctic and its climatological phenomena represent to a vampire? While an interesting take on vampire mythology in certain respects, the most interesting aspect of comics is its combinatory narrative conceit. As a vampire story-cum-arctic survival narrative, part of the success of Niles and Templesmith's concept rests on the fact that while the threat facing the inhabitants of Barrow is folkloric/mythological, "the horrors of being caught in a blizzard, of the human body succumbing to freezing temperatures, frostbite, and fatal cases of hypothermia [...] the impact of the arctic horror is utterly real" whereby the narrative is pregnant with the obvious and surreptitious ways in which "extreme weather conditions can break down a man, woman, or child, both physically and psychically" (Hicks, 2018). From the perspective of a survivor of the initial Barrow massacre, the combination of the Arctic and the vampire presence represents an impasse/trap, one captured when Stella asks Eben to run, to which he responds by saying, "No. We won't stand a chance. If they don't get us, the cold will" (Niles \& Templesmith, 2002, p. 67).

Caught between the figurative white fangs of the Arctic itself, and the folkloric fangs of the undead, the relationship between Barrow, its inhabitants, and its predators is one of essential conflict, horror, and tension. Niles sums up this relationship in a way that is extremely evocative in terms of engendering an interconnected sense of the appetitive, terrifying, and inevitable: "a small, remote town where the sun doesn't rise for weeks on end. It was true. A heaven on Earth for the dead. So they gathered 


\section{Figure 2}

The Massacre Begins
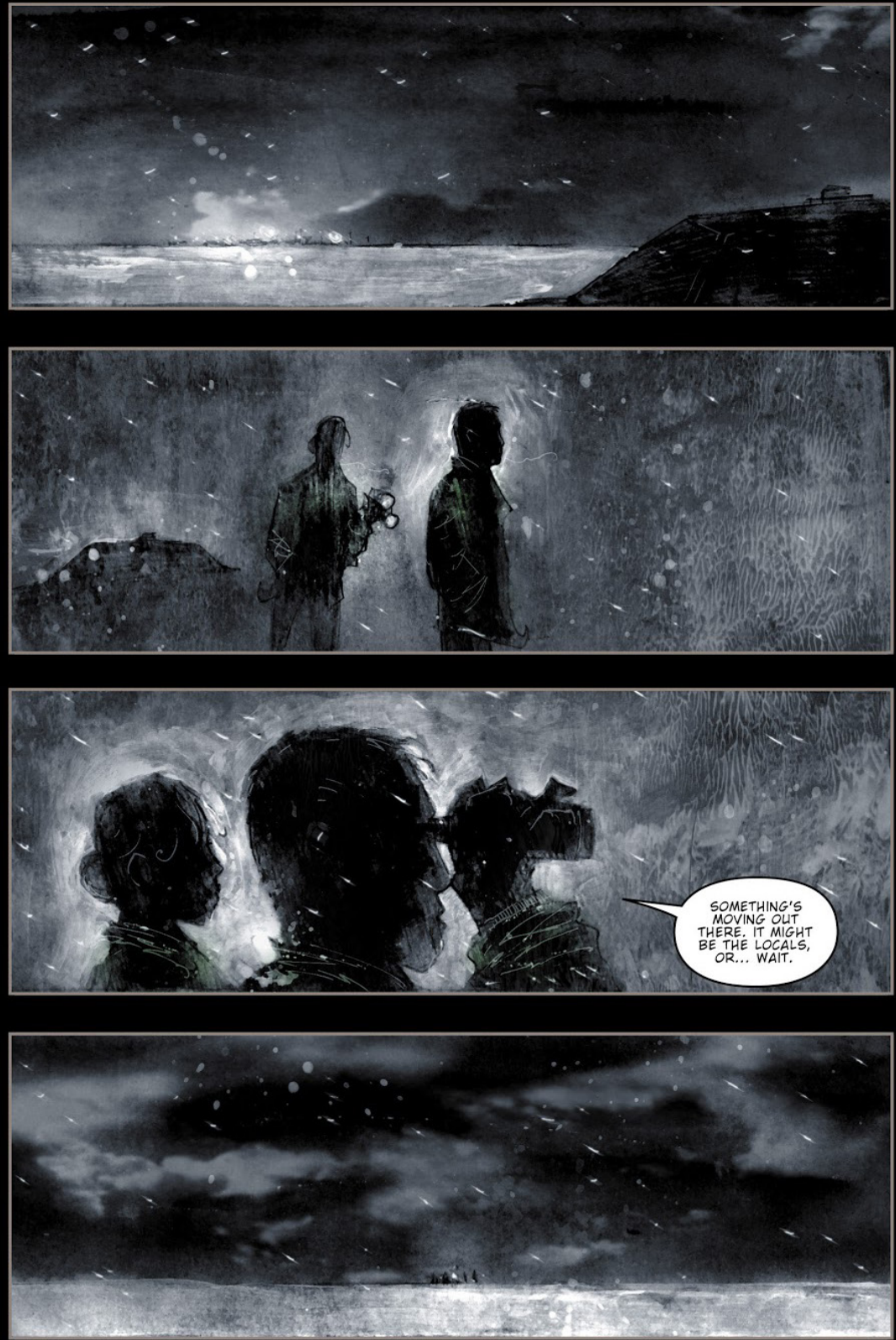
White Fang Ally: The Arctic As Eden of Death in 30 Days of Night

\section{Figure 3}

The Massacre Begins
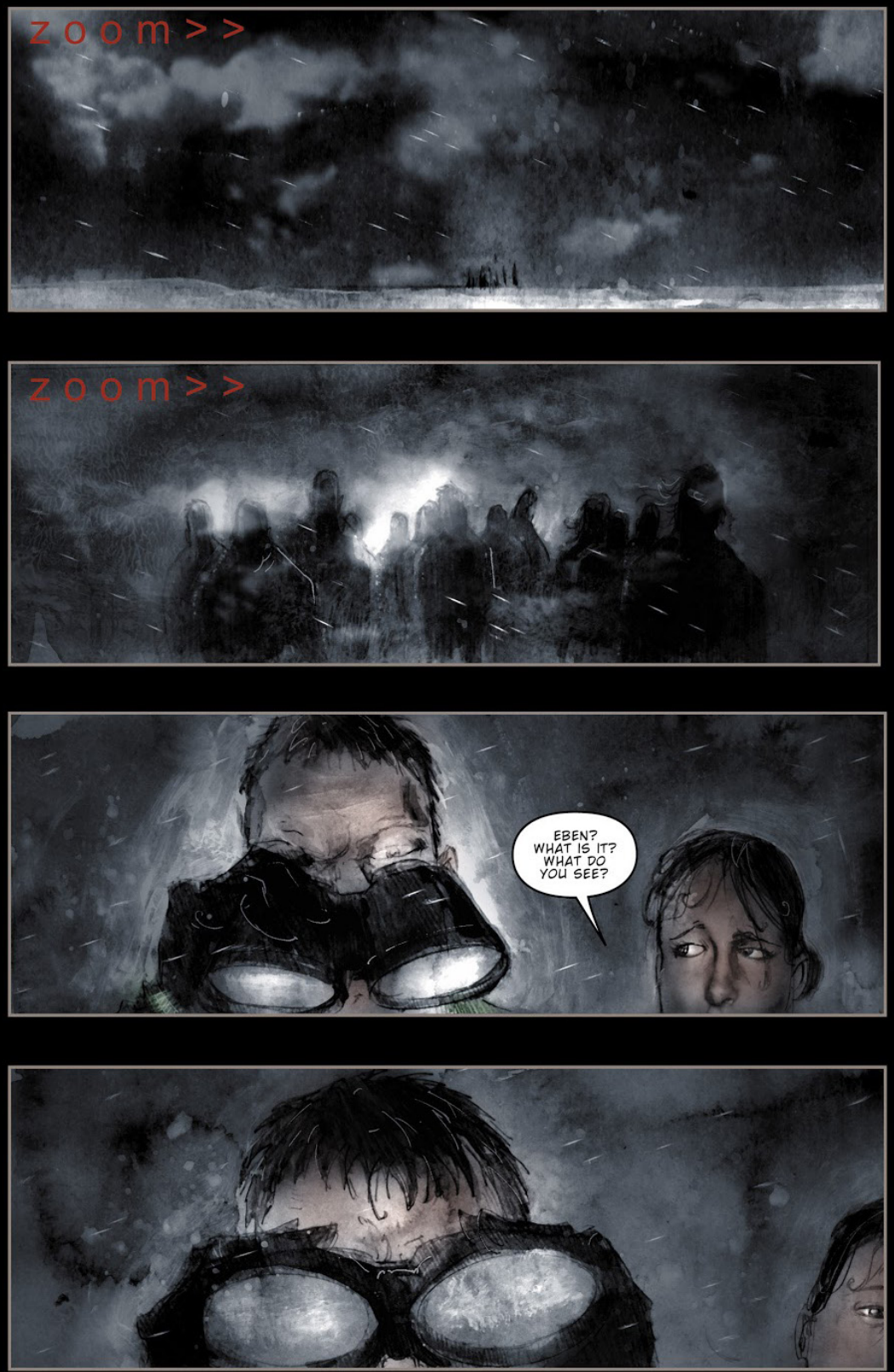
and travelled across the Earth to attend a feeding frenzy. It was the perfect plan" (Niles \& Templesmith, 2002, pp. 32-3). He goes on to describe the vampire advance and its subsequent massacre opened up and closed off by the Arctic's unusual weather:

They came quickly, walking over the frozen tundra, cutting off communication and escape routes as they marched. They have feasted on the men, women and children of Barrow without mercy and without pause. This is the world of which they have only dreamed. Endless night and an endless supply of blood and meat: This is how it is meant to be: humans, like bottles, waiting for their caps to be popped. Some of the blood-meat try to escape. But there's no way out. They catch every vehicle. They have destroyed every computer, phone, and radio. (Niles \& Templesmith, 2002, pp. 33-39)

In terms of this relationship between the Arctic and the vampire as an undead predator, Niles intensifies the menace and threat of the latter by combining it with the numerous natural dangers of the former. From a vampire's perspective, Barrow and its situation in the harsh Arctic climate inverts numerous quintessential assumptions of the vampire being a skilled, active, and tenacious predator. In a very real sense, the mixture of vampires, the Arctic, and a small isolated town can be seen, on the one hand, as an ecocritical commentary on nature's (through un-nature/the undead) violent reclamation of said biome. On the other hand, the fact that the vampires, rather intelligently, use the arctic as a slow-trap icebox and as such, could equally be read as a critique of the (over)elaborate melodramas of traditional Gothic vampires.

The viscerality of the paradoxical agoraphobic claustrophobia of vampireplagued Barrow, and Niles' portrayal of the Arctic more broadly, is dependent on the intersection of numerous actors and concepts. As Veland and Lynch note, "at the Arctic ice edge, a multitude of story-lines intersect, drawing on a diversity of histories, identities, methodologies, perspectives on risk, and hopes and visions for the future" (Veland \& Lynch, 2016, p. 9). In view of this inhuman-human-Arctic assemblage, borrowing from Estok, Barrow can be described as an ecophobic site, where ecophobia refers to the fear of the loss of human agency when confronted with nature (Estok, 2011, p. 4). The environmental dangers of the tundra are circumscribed primarily by the climate's scarcity of resources, made more exigent by the fact that the biome is also a site of predation, embodied primarily by arctic wolves and polar bears. Also, and ironically anathemic to the physiological weaknesses 
of vampires, the Arctic is also known for dangerous levels of ultraviolet radiation (which, during the month of darkness is no longer a threat to the undead). Regarding the weather itself, Brett Smith notes that "while daytime highs in the summer months average around 50 degrees Fahrenheit, the average daily high temperature during the long Arctic winter is 0 degrees - making frostbite and hypothermia the most immediate environmental dangers associated with the tundra" (Smith, 2017). Here, the nosferatu of Niles' narrative take advantage of the fact that the Arctic's weather forces human beings to conserve energy and avoid overexertion. This means that communities in such climates, like Barrow, discourage widespread movement, and promulgate social and communal practices that place a premium on staticity, nearness, and stillness. From a vampire's perspective, the weather acts as a kraal, keeping the population of prey radically remote in one sense, and radically integrated in another. In terms of the resource scarcity, Smith notes that "the extreme cold of the tundra also places a high demand on the body - spiking calorie usage per day up to as high as 12,000 in some cases. This high rate of metabolism exacerbates the fact that there is very little readily available food in the tundra [...] Animals in the Arctic are high in fat and can be a source of food - if they can be caught" (Smith, 2017). From the perspective of Niles' predators, the adage 'if your quarry goes to ground, leave no ground to go to' is pertinent in explaining how the vampires allow the scarcity of resources for their prey turn into an abundance of prey for themselves.

The survivors of Marlow's first wave attack against Barrow, on little resources, are faced with two options: starve, or risk exposure, not only to the natural dangers of the elements, but the un-natural threat of the vampire raiders. Here, the Arctic inverts the relationship between human beings and the various resources of the Arctic. The introduction of a new apex predator in an already resource scarce environment, one that, being undead, can leverage the harsh inclemency of the Arctic as a boon or ally in the broadest sense, turns the former hunter of scarce prey into comparatively abundant prey themselves. This inversion is also one of substitution. Like polar bears, which "are typically interested in hunting seals, they have been known to track and kill seal hunters", using the Arctic, the vampire turns the hunter into the prey (Smith, 2017). Ultimately, the combination of vampires and the Arctic troubles and further exacerbates humanity's limited agency in such extreme climates, underscoring the latent ecophobia of 


\section{Figure 4}

Barrow, Alaska - A Banquet for the Undead

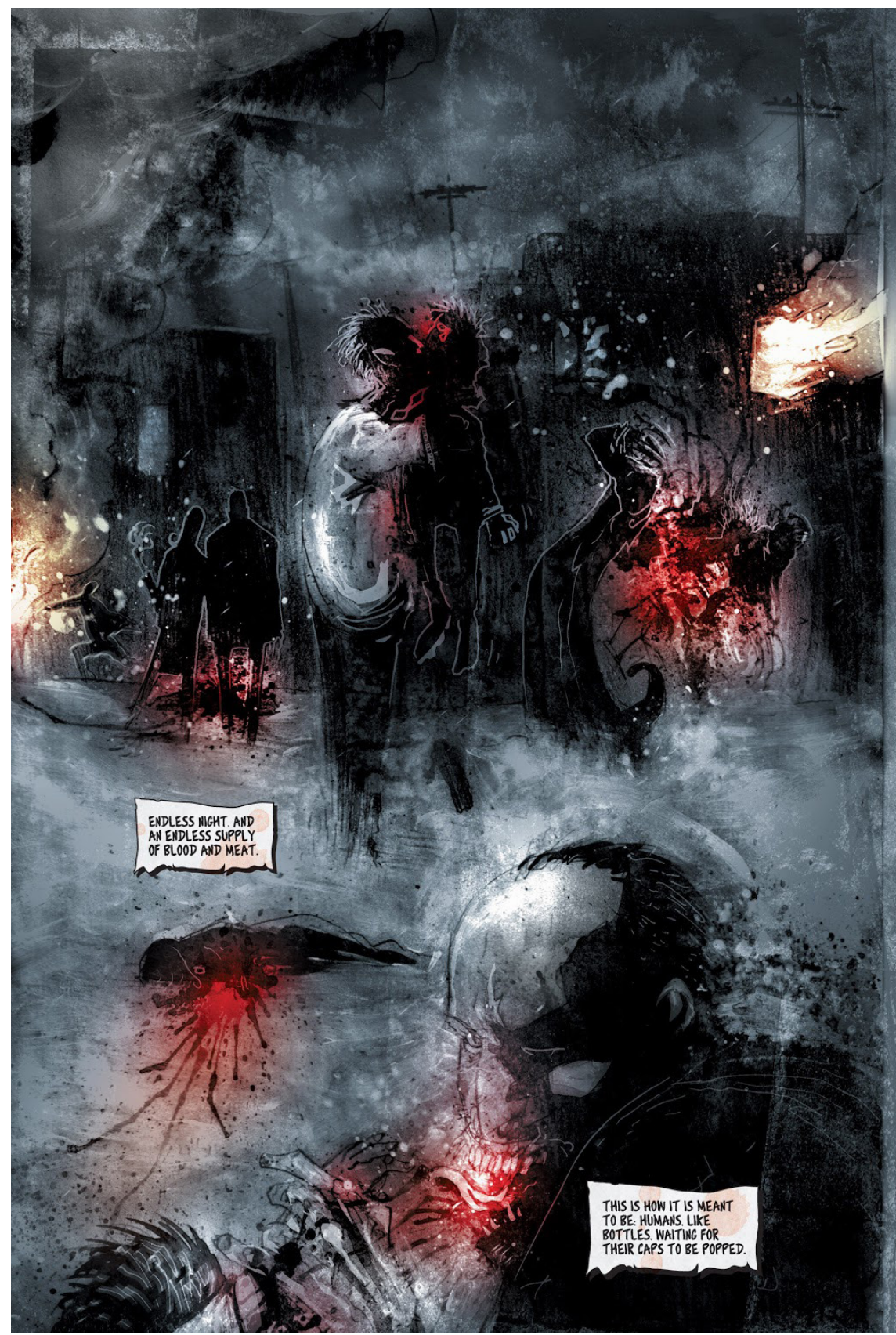




\section{White Fang Ally: The Arctic As Eden of Death in 30 Days of Night}

this particular biome. It is for these combinatory reasons that Marlow gleefully, (blood) drunkenly describes the Arctic, and Barrow within it, as an Eden of death:

I don't know why we never thought of it. No sunlight for weeks on end. We can feed as we wish and never sleep. No need to hide during the light hours wondering if they'll find our sleeping body! It is just as I described in our communications. Here we rule. The humans hide and wait for us to find them. We can feast enough to make us strong for a full year! And none have been turned. I gave strict orders that all victims should be decapitated after bleeding and feeding. It's paradise! (Niles \& Templesmith, 2002, p. 51)

This Arctic-human-undead combination and its exacerbation of ecophobic psychoemotional affects further elicits horror as defined by Eugene Thacker, which is less concerned with fear, but rather with "a confrontation with the unthinkability of the world" (Thacker, 2011, pp. 1-2). Latent in this definition is the notion of limits and constraints, which Thacker theorizes against three frameworks of the relationship between human beings and the world. The first, which is the only one this paper is interested in, is 'the-world-for-us', an anthropocentric worldview that persists even when the world "resists, or ignores our attempts to mold it into the world-for-us" (Thacker, 2011, p. 4). In this sense, both the Arctic and the vampire in it in 30 Days represents an anti-human space momentarily populated by anti-human figures. From a Thackerean perspective, the "whole bestiary of impossible life forms" in genre horror, such as the vampire, "plays a central role in exposing and critiquing our assumptions that the world exists for us" (Thacker, 2011, p. 8; Merola, 2014, pp. 32-33). It is through the use of climate to invert the inter-species hierarchy and order of predation that the insertion of vampires in such a milieu allows Niles and Templesmith to interrogate Arctic "networks of violence, which include both the harvesting of marine mammals and conflict between men that is linked to resource extraction", all of which coalesce in the comic into a narrative and conceptual framework in which the inhuman and the human assemble into a network of death (Merola, 2014, p. 26). This network is, again, predicated on clever, fascinating, and even sublime paradoxes. It is one of disintegrated merger and mutually exclusive coherence wherein which "the structural violence of resource extraction with the technologies that make it possible (men, ships, hooks, knives, guns, tryworks, trade networks) [combined with the presence of marauding vampires] highlights the confusion of natural, unnatural, and supernatural" that 
animates the text (Merola, 2014, p. 26). In this sense, Barrow and vampires form an inhuman ecology, one in which the "slippage between inhumane and inhuman" which ultimately redound to death and/or survival, are exacerbated by the arctic setting itself (Merola, 2014, p. 26).

\section{DISTAL ZONES \& CIPHER SOCIETIES: THE ARCTIC AS HETEROTOPIA OF DEATH}

In "Of Other Spaces: Utopias and Heterotopia” (1984), Foucault discusses the concept of heterotopia by providing and analysing various styles and principles thereof. While the author gives no clear definition of a heterotopia to encapsulate a latent principle running through the six forms or manifestations of heterotopia he discusses, I offer the following as my working definition of heterotopia: heterotopias are spaces wherein which the typified onto-existentialsm, sociopolitical and cultural praxes, as well as all flows of biopower of a given culture break down at most, or are renegotiated at least. In this sense, the term heterotopia describes the human geographical phenomena of spaces and places that function in non-hegemonic ways or conditions. Heterotopic spaces are spaces of otherness, liminality, fusion, confusion, play, and dynamism. They can hybridize various modalities and states of matter, they can be physical and ephemeral simultaneously like the space of a telephone call or one's reflection in the mirror.

The ostensibly simple reterritorialization of the vampire from its familiar settings of Gothic edifices, manor houses, abbeys, and castles to the frozen expanses of the Arctic reveals how Niles and Templesmith rely on the natural phenomena of the Artic to combine and merge the supernatural and the natural. It is also a fundamentally paradoxical move in the context of the 30 Days diegesis because the combination of disparate, distal, and/or antipodal modalities of life, un-life, and an ostensibly antilife climate lead to destruction as opposed to multiplication. Here, there are interesting theoretical, specifically onto-existential, consequences of this device. The most identifiable being the fact that in the space of Barrow, "natural, built, nonhuman, and inhuman elements [merge] into [...] a field against which discrete selves disappear" (Merola, 2014, p. 364). In this sense, as a distal zone plagued by a 'cipher society' which I use to refer to a population of beings of indeterminate number or nature, Barrow is as insular as a coven of vampires which makes each community the perfect 
foil for one another. Barker and Templesmith give the reader numerous hybridizations such as the prey-pack, hunter-Pack, and obvious hybrid, Ethan. The insertion of vampires into the always-already natural perilousness of Barrow turns the Arctic into a site of ontological insecurity as well. As Jeffrey Jerome Cohen notes, "the too precise laws of nature as set forth by science are gleefully violated in the freakish compilation of the monster's body" (Cohen, 1996, p. 6). In the anthropomorphization of the cold relentlessness of the Arctic through the figure of the vampire, Barrow is a site of heterotpoic monstrous bodies, embodied sites of conceptual merger, breakdown, multiplication, and disintegration, reterritorialized into a site in whose natural climate the typical cyclicality of nature simultaneously breaks down.

In terms of heterotopias of time, Foucault states that there are heterotopias of indefinitely accumulating time, for example museums and libraries in whose spaces objects from various points of time are brought together and though existing in time, are shielded from temporal decay by virtue of being housed therein. According to Foucault, museums and libraries have become heterotopias in which time does not necessarily stop, but rather represent a "will to enclose in one place all times, all epochs, all forms, all tastes, the idea of constituting a place of organizing in this way a sort of perpetual and indefinite accumulation of time in an immobile place" (Foucault, 1984, p. 7). In this way, heterotopias of time are spaces in which objects from varying points of time can be physically dislodged from their original chronotopes. A second type of heterotopia of time concerns the opposite of infinity, namely, the brevity of time. Foucault refers to this as "the mode of the festival" (Foucault, 1984 , p. 7). Foucault chooses the fairground as an example of such a space, one that accumulates heteroclite objects and praxes which stand idle for the duration of the year, save on specified days/weeks where they teem with activity, albeit only for a truncated period of time.

In an exchange between Eben and Vicente, the former describes the onset of vampirism as "endless hunger", Vicente then adds that it is an endless hunger "for endless life" (Barker, 2002, p. 76). In terms of the relationship between heterotopias of time and what this paper refers to as a heterotopia of death, the operative term in the above quotation is infinite. In 30 Days, Niles avails himself of the natural disruption of climatological processes and cycles used to measure time in the Arctic (specifically the solar and lunar cycles) to turn Barrow into a heterotopia of death, one in which the more common natural cycles of time-keeping breakdown. In Barrow, this natural disruption of time results in the accumulation of days and darkness, the spacio- 
temporal prerequisites for vampire predation and simultaneously, human victimhood. In Barrow, it is not necessarily that heterogenic and distal objects are displaced from their chronologies and shielded from the ravages of time itself by being frozen or isolated therein. Quite the opposite. In Barrow, timelessness does not guarantee survival but its opposite, namely death. Here, time and timelessness ultimately redound to the same thing in Barrow: death.

This paper recognizes that the concept of a heterotopia of death must take into account the variance in perspective value for those beings circumscribed therein. What does a heterotopia of death mean to a vampire? From a vampire's perspective, in Barrow, as Marlow states, "for once...time is on OUR side" (Niles, 2002, p. 48). Being that the vampire is a physical embodiment of the onto-existential condition of being non-being, the living-dead, the vampire is always-already heterotopic in corpore. As immortal beings who, in some instances, have survived millennia, and moved through, participated in, marked, and been marked in turn by various heterogeneous times, epochs, and ages, the figure of the vampire, not unlike the figure of the timetraveller, brings together various points of time in embodied form. Though Vicente, Marlow, and the rest exist in time, their onto-existential condition as vampires shield them from temporal decay. Here, Niles' reterritoiralization of the vampire to the distal zone of the Arctic makes the vampire an embodiment, a literal anthropomorphization, of the preservative attributes of ice itself and the sub-zero more broadly. There are interesting symbolic resonances in this association that, to me, suggest something quite radical: to be less than alive is simultaneously to be beyond the end of life; to be onto-existentially cold, dead, and/or sub-zero is equally to be, barring the aforestated interventions, infinite.

However, it is also true that unlike the immobile sites for the accumulation of time Foucault notes, such as libraries and museums, the timelessness of Barrow is not indefinite. The fact that this heterotopia of death is itself paradoxically temporary means that Barrow is simultaneously representative of both overarching aspects of the heterotopia of time: infinite in terms of the vampire presence and un-natural use of the natural disruption of time that occurs there, as well as brevity in that the entire phenomenon lasts only 30 Days. However, in Barrow, 30 days is both the blink of an eye and an eternity, a paradoxical and unstable movement of disrupted time that occurs against the seemingly unchanging backdrop of the Arctic itself, a climate seemingly indifferent to the paradise of death it engenders. The combination of these phenomena turn Barrow, from a vampire's perspective, into both a refrigerator and a fairground. 


\section{White Fang Ally: The Arctic As Eden of Death in 30 Days of Night}

What are the implications of the above theorization as developed heretofore? I assert that the implications are several but ultimately redound to one concept. In this sense, the above critical review of this particular vampire story and its setting can offer another facet in theorizations and critique of the forces of "vampiric capitalism" as adumbrated by Karl Marx in digital late capitalist (or techno-feudal, depending on your view) global life. Like the nosferatu's unrelenting predation of the inhabitants of Barrow, the oppressive predation of capitalism's unslaked pressure toward and pursuit of profit and productivity is no longer limited to day/night temporal arrangements, where night might represent a sense of reprieve or relaxation from the ardours of the working day. Exacerbated by global conditions, such as the ongoing Covid19 pandemic and the impending climatological catastrophes already given prelude in increased extreme weather, the ostensible and necessary isolation experienced by global society in order to prevent the spread of infection cannot, ironically, protect us from the spread of capitalism's unslaked pressure toward and pursuit of profit and productivity. Day or night, the home, the once private remit of respite, has necessarily become the work-space. We live where we work, and work where we live. Day or night our digital devices issue alerts of possible revenue streams opening up as unforeseen emergence of the radical changes in the global economy due to the ongoing global health crises, or, equally, the dissipation of former economic means on account of the same changes. In this way, we live in an endless working day, as inhabitants of Barrow experience an endless night during 30 Days. As the pandemic continues, the sense of scarcity, precarity, and isolation all elongate - from new more communicable strains of the virus, to worsening supply-chain issues and delays, to the disappearance or radical stasis of entire global sectors and industries, it seems to me that vampiric capitalism has less and less to feed on save our own horror of its unrelentingness and the increasing vastitude of socioeconomic, political, cultural, and ecological precarity along with it. With less and less exploitation of natural resources available, and its correlate in the vampires' exploitation of human communities in the comic (which, remember, is a limited population; that is to say, even the best banquet eventually ends), it seems that capitalism has only one reliable, truly inexhaustible resource to exploit: human fear. While Jean Baudrillard described capitalist society as a 'desert of the real', I would update that description in view of the above analysis and suggest that like 30 Days's Barrow, contemporary late digital capitalist global society is best described as an Arctic of death. 


\section{REFERENCES}

Barker, C. (2002). Cold blood [Introdution]. In S. Niles, \& B. Templesmith, 30 Days of Night. IDW Publishing.

Bloom, C. (2010). Gothic Histories: The Taste for Terror, 1764 to Present. Continuum International Publishing Group.

Cohen, J. J. (1996). “Monster Culture: Seven Theses. In Jeffrey Jerome Cohen (Ed.), Monster Theory: Reading Culture (pp. 3-25). University of Minnesota Press.

De Vore, D., Domenic, A., Kwan, A., \& Reidy, N. (n.d). The Gothic Novel. [Webarchive]. https://web.archive.org/web/20110413003858/http://cai.ucdavis.edu:80/ waters-sites/gothicnovel/155breport.html. Accessed 2 Sept. 2018.

Estok, S. C. (2011). Ecocriticism and Shakespeare: Reading Ecophobia. Palgrave Macmillan.

Foucault, M. (1984). Of Other Spaces: Utopias and Heterotopias (Jay Miskowiec, Trans.). Architecture /Mouvement/Continuité (Octobre).

Hicks, M. P. (2018). The Horror Book Review Digest, Vol 1. High Fever Books.

Hillard, T. J. (2009). 'Deep Into That Darkness Peering': An Essay on Gothic Nature. Interdisciplinary Studies in Literature and Environment, 16(4), 685-695.

Hillard, T. J. (2013). From Salem Witch to Blair Witch: The Puritan Influence on American Gothic Nature. In Andrew Smith \& William Hughes (Eds.), EcoGothic, (pp. 103-119). Manchester University Press.

Khair, T. (2009). The Gothic, Postcolonialism and Otherness: Ghosts from Elsewhere. Basingstoke: Palgrave.

Koenig-Woodyard, C. (2018). The Mathematics of Monstrosity: Vampire Demography in Richard Matheson's I Am Legend. University of Toronto Quarterly, 87(1), 81109.

Mackenzie, L., \& S. Posthumus. (2013). "Reading Latour Outside: A Response to the Estok-Robisch Controversy." Interdisciplinary Studies in Literature and Environment, 20(4), 757-777. 
Matheson, R. (1995). I Am Legend. Tom Doherty. (Original work published 1954).

Merola, N, M. (2014). 'For terror of the deadness beyond': Arctic Environments and Inhuman Ecologies in Michelle Paver's Dark Matter.” Ecozon@, 5(2), 22-40.

Morton, T. (2010). “The Dark Ecology of Elegy.” In Karen Weisman (Ed.), The Oxford Handbook of Elegy, (pp. 251-271). Oxford University Press.

Niles, S., \& Templesmith, B. (2002). 30 Days of Night. IDW Publishing.

Philips, D. (2003). The Truth of Ecology: Nature, Culture, and Literature in America. Oxford University Press.

Shelley, M. W. (1823). Frankenstein: Or, the modern Prometheus, (2 vols, 2nd ed.). G. and W. B. Whittaker.

Smith, B. (2017). Environmental Dangers in the Tundra. Sciencing, https://sciencing. com/environmental-dangers-tundra-23668.html. Accessed 2 Sept. 2018.

Taylor, M. A. (2012). "The Nature of Fear: Edgar Allen Poe and Posthuman Ecology." American Literature, 84(2), 353-379.

Thacker, E. (2011). In the Dust of This Planet: Horror of Philosophy, Vol. 1. ZeroBooks.

Trexler, A. (2012). Novel Climes: Anthropocene Histories, Hans-Jörg Rheinberger's Trace, and Clive Cussler's Arctic Drift. The Oxford Literary Review, 34(2), pp. 295-314.

Trexler, A., \& Johns-Putra, A. (2011). Climate Change in Literature and Literary Criticism. Wiley Interdisciplinary Reviews: Climate Change [Online], pp. 185200. http://onlinelibrary.wiley.com/doi/10.1002/wcc.105/abstract

Veland, S., \& A. H. Lynch. (2016). Arctic ice edge narratives: scale, discourse and ontological security. Area, 49(1), 9-17. 